\title{
Antifungal activities of the rhizome extract of five member Zingiberaceae against Candida albicans and Trichophyton rubrum
}

\author{
MUHAMMAD EVY PRASTIYANTO, NI'MATUR ROHMAH, LESITA EFENDI, RAHMATIA ARIFIN, \\ FANDHI ADI WARDOYO", WILDIANI WILSON, ANA HIDAYATI MUKAROMAH, SRI SINTO DEWI, \\ SRI DARMAWATI
}

Departement of Medical Laboratory Technology, Faculty of Nursing and Health Science, Universitas Muhammadiyah Semarang. Jl. Kedungmundu Raya 18, Semarang 50273, Central Java, Indonesia. Tel: +62-24-76740288, `email: fandhiadi@unimus.ac.id@unimus.ac.id

Manuscript received: 24 November 2020. Revision accepted: 26 February 2021.

\begin{abstract}
Prastiyanto ME, Rohmah N, Efendi L, Arifin R, Wardoyo FA, Wilson W, Mukaromah AH, Dewi SS, Darmawati S. 2021. Antifungal activities of the rhizome extract of five member Zingiberaceae against Candida albicans and Trichophyton rubrum. Biodiversitas 22: 1509-1513. Fungal infections have now become serious health issues. One of the strategies to avoid the problems of fungal infections is by using natural product from plants that are effective against many human pathogenic fungi. The study portrayed the use of the extracts of plant rhizomes as the alternatives to fight against number of human pathogenic fungi. This research aimed to investigate the antifungal activities of crude ethanol extract of five member of the family Zingiberaceae (Curcuma longa, Alpinia galanga Zingiber officinale. var. rubrum, Zingiber officinale var. officinarum and Zingiber officinale var. amarum), which are widely used as folk medicines against Candida albicans and Trichophyton rubrum. Crude ethanol extracts of five members of Zingiberaceae were evaluated for their antifungal activities and the results were calculated based on the zones of inhibition using the diffusion method. The extract showed antifungal activity against Candida. albicans in the agar well diffusion assay (10.2-27.1 mm inhibition diameter) and against T. rubrum (27.3-44.3 mm inhibition diameter). The data have revealed that all rhizomes have the potential to be developed as antifungal agents, particularly against $C$. albicans and T. rubrum. Studies on the antifungal activity against yeast-like (C. albicans) and filamentous (T. rubrum) can provide new information about the benefits of members Zingiberaceae as a source of natural antifungal. Researchers can select the type of rhizome that has more potential for further extraction to obtain pure compounds that can be used as antifungals.
\end{abstract}

Keywords: Antifungal activity, Candida albicans, Trichophyton rubrum, Zingiberaceae, zones of inhibition

\section{INTRODUCTION}

Fungal infections have become a serious threat to human health and they are associated with at least 1.5 million deaths worldwide each year (Brown et al. 2012). Fungal infection is a common problem occurs at least 20 . $25 \%$ of the world's population. Since 1980, the pravalence of fungal infection has been increased in many patient groups (Soetojo and Astari 2016). Human infections those involving fungal, constitute a serious problem, especially in tropical and subtropical developing countries including Indonesia.

Indonesia is one of the countries with tropical climate, that has climate characteristics such as high temperature and humidity. The characteristics of the climate in Indonesia cause the skin to become sweaty and moist. Based on the climatic conditions, lack of knowledge about fungal infections, many people who do not maintain personal hygiene and get exposed to the risk factors of candidiasis in Indonesia. Candidiasis also being the third leading cause of fungal infection in the United States and Europe (Puspitasari et al. 2019).

Dermatophytes and Candida spp. are the main infection causing pathogens. Infections caused by the genera Candida and Trichophyton are responsible for more than 300 million acute or chronic infections worldwide (Boral et al. 2017). Dermatophytes are a group of fungi responsible for the most common fungal infections in humans. Arthrodermataceae, Onygenales infect keratin tissues such as hair, nails, and skin. Dermatophytosis is known as "ringworm" or "tinea" with circular lesions on the skin of an infected person (Reiss et al. 2012). Trichophyton rubrum is the fungal pathogen causing tinea infections on nails and skin (Ghannoum and Isham 2014; Pathania et al. 2018; Rudramurthy et al. 2018; Singh et al. 2018; Zhan and Liu 2017), and is responsible for $69.5 \%$ of all Trichophyton infections (Hube et al. 2015). T. rubrum is the main cause of chronic superficial infections that affect human psychology and social life (Kong et al. 2015).

While candidiasis is one of the most common infections, widely recognized as major cause of mortality, morbidity and considerable health expenditure (Ashley et al. 2012; Calandra et al. 2016; Kollef et al. 2012; Lortholary et al. 2014). The incidence of Candidiasis in Asia from several epidemiological studies suggested that $C$. albicans is the most frequently identified species with an average of 56\% of cases of Candidiasis (Lewis and Williams 2017; Muadcheingka et al. 2015). Candida albicans is still the leading cause of Candida bloodstream infection by percentage $33.3 \%$ in Singapore, $55.5 \%$ in Taiwan 55.6\%, and 41\% in Japan (Puspitasari et al. 2019). The genus Candida consists of 377 species which are 
members of Saccharomycetales. C. albicans is the cause of opportunistic and nosocomial infections (McManus and Coleman 2014). C. albicans is ranked among the common five infectious agents causing sepsis and infection of mucosal surfaces of the gut (Vincent et al. 2009). Candida can cause severe and invasive infections because it can manifest as candidaemia, disseminated candidiasis, endocarditis, meningitis, endophthalmitis, and infections of other internal organs (Pappas et al. 2016).

The conventional treatments for fungal infection are the use of antifungal agents, such as Azole (ketoconazole, miconazole, and imidazoles), Polyene (nystatin, pimaricin, and amphotericin B), Allylamine (naftifine and terbinafine), Morpholine (amorolfine), and Antimetabolite such as 5-Fluorocytosine. However, the uncontrolled use of antibiotics contributes to the emergence of multidrug resistance fungal strains (Cretton et al. 2017; Piras et al. 2018). So novel antifungal agents are needed from natural biological sources. Biological antifungal can be obtained from the Actinomycetes (Sipriyadi et al. 2016), Honey (Oro et al. 2015), saliva (Conti et al. 2013), Venoms of the snakes (Siigur et al. 2019), and Plant (Espino et al. 2019).

Utilization of plants as medicine has been done since ancient times, (Al-dhabi and Arasu 2016; Elango et al. 2016; Manh et al. 2017). Many plants are used as traditional medicines having anticancer (Adnan and Ahmed 2019), antioxidant (Diniyah et al. 2020), antibacterial (Prastiyanto et al. 2020a; 2020b) and antifungal (Kader et al. 2011) properties. The members in Zingiberaceae have been recognized in uses of medicine such as antibacterial (Wibowo et al. 2020), antifungal (Akter et al. 2018), anticancer (Mahomoodally et al. 2019), anti-arthritic (Murugesan et al. 2020) and antioxidant (Ghafoor et al. 2020).

The extraction process is carried out with the aim to taking the active compound present in the plant. Solvents commonly used in the extraction of plants and herbs such as ethanol, methanol and acetone. Apart from the solvent in the extraction process, the method that used in the extraction process is also important to considered. Extraction methods that are often to use such as maceration, soxhletation, infusion, and percolation. The easiest and simplest extraction method to do is maceration method. The maceration method does not require heat, so it does not have the potential to damage the active compounds in the Zingiberaceae.

This research was conducted to investigate the potential of members Zingiberaceae (Curcuma longa, Alpinia galanga, Zingiber officinale var. rubrum, Zingiber officinale var. officinarum and Zingiber officinale var. amarum) as antifungal agent against $C$. albicans and $T$. rubrum. The data of study are useful for researchers in the fields of medicine, chemistry, biology and pharmacy. By incorporating the data, the researchers can select the types of rhizomes that are more potential for further extraction to obtain pure compounds than can be used as antifungals. The data are insightful to be incorporated for further developments or experiments because researchers can choose the types of rhizomes that are prospective for further extraction to attain pure compounds that can be used as antifungals

\section{MATERIALS AND METHODS}

\section{Plants collection and fungal preparation}

The rhizomes of five member Zingiberaceae (Curcuma longa, Alpinia galanga, Zingiber officinale. var. rubrum, Zingiber officinale var. officinarum and Zingiber officinale var. amarum)) were obtained from a home garden in Kedungmundu, Semarang, Indonesia. The Rhizomes were washed with tap water to remove all unwanted materials, cut off, rinsed with sterilized distilled water, and then sun dried for three days. The dried rhizome was then ground into a fine powder using a grinding machine and stored in a sterile air-tight container until further process. Fungal isolates (T. rubrum and C. albican) were isolated from patients of the Dr. Kariadi Hospital, Semarang, Indonesia. The Fungal were subcultured for $48 \mathrm{~h}$ at $35 \pm 2{ }^{\circ} \mathrm{C}$ on Sabouraud Dextrose Agar (SDA) medium.

\section{Preparations of extracts}

The extracts of rhizomes were prepared with a maceration method using ethanol solvent. $100 \mathrm{~g}$ of powdered rhizomes of five members of Zingiberaceae (Curcuma longa, Alpinia galanga, Zingiber officinale var. rubrum, Zingiber officinale var. officinarum and Zingiber officinale var. amarum) was soaked in $300 \mathrm{~mL}$ of ethanol for 24 hours under normal room temperature and protected from light in a rotary shaker. The replacement of the solvent was carried out until the solution became clear with the assumption that there was not any active compound contained in the dry powder. The supernatant was filtered on Whatman filter paper grade 1. The solution was concentrated under reduced pressure using a rotary evaporator at $50^{\circ} \mathrm{C}$. The crude extracts were collected and allowed to dry at room temperature.

\section{Antifungal susceptibility test}

The antifungal activities of the rhizomes of five plants were evaluated using a well-diffusion assay that was modified (Sales et al. 2016). In this method, $100 \mu \mathrm{L}$ of each microorganism test equivalent to a 1 McFarland standard was inoculated on the SDA. It was later spreaded on the surface of medium by using a sterilized glass spreader. After 10 minutes of inoculation, the wells were prepared using sterilized steel corkborer $(1 \mathrm{~cm}$ diameter). Wells were made in each plate, out of which five wells were loaded with the various concentrations of five plants, $\mathrm{Cl}$, Ag (0.25-1.00 mg/mL) and Zr, Zo and Za (0.05-0.2 $\mathrm{mg} / \mathrm{mL}$ ). All plates of $C$. albicans were then incubated aerobically at $35 \pm 2{ }^{\circ} \mathrm{C}$ for 24 hours and plates of $T$. rubrum were incubated aerobically at $35 \pm 2{ }^{\circ} \mathrm{C}$ for five days. The antifungal activities of the extracts were determined by measuring the diameter of the inhibition zone in $\mathrm{mm}$ against the tested fungi. 


\section{Phytochemical screening}

All extracts were screened for the presence of different classes of secondary metabolites, including alkaloids and flavonoids using previously described methods (Wadood et al. 2013).

\section{RESULTS AND DISCUSSION}

\section{Yield of plant extracts}

The data provided in this article pinpointed the potential of antifungal activities of ethanolic extracts of Curcuma longa $(\mathrm{Cl})$, Alpinia galanga $(\mathrm{Ag})$, Zingiber officinale. var. rubrum (Zr), Zingiber officinale var. officinarum (Zo), and Zingiber officinale var. amarum $(\mathrm{Za})$ against $C$. albicans and T. rubrum.

We presented the data acquired from extraction, antifungal susceptibility test, and phytochemical screening. The ethanolic extracts of five rhizomes were calculated for the crude extract (Table 1). All the extracts indicated that the constituents were relatively polar.

\section{Antifungal activities}

The agar well diffusion method is a method that is routinely used in clinical laboratories. The antifungal activities of the extracts were determined by measuring the diameter of the inhibition zone in mm against the tested fungi. The antifungal activities of the five extracts were assayed in vitro by agar diffusion method against $C$. albicans and $T$. rubrum. The zones of inhibition are presented in Figure 1. All plants demonstrated the zones of inhibition against $C$. albicans and T. rubrum.

\section{Phytochemical}

The screening of the phytochemical composition was conducted for all plants. The secondary metabolites are shown in Table 2.

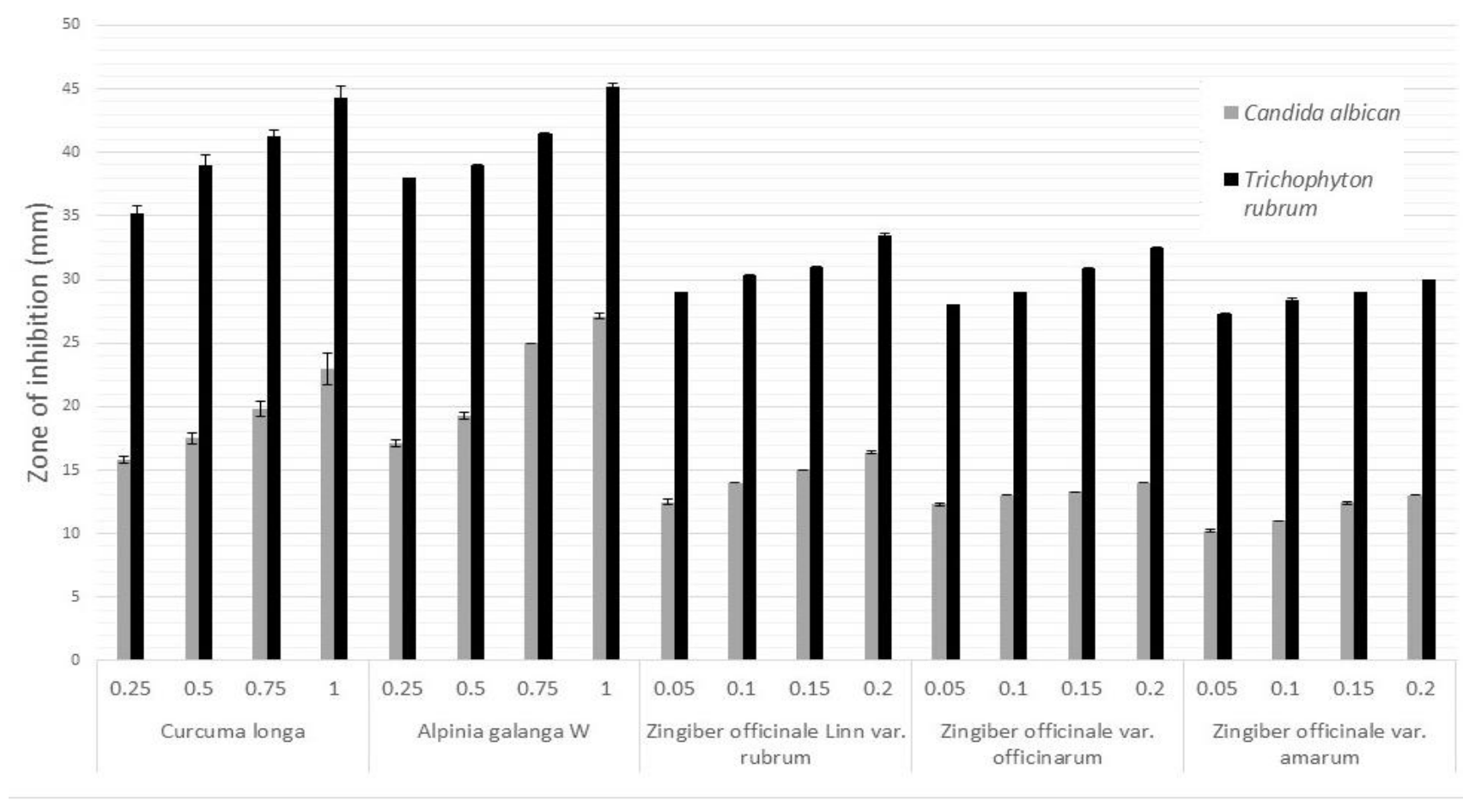

Crude Extract $\mathrm{mg} / \mathrm{mL}$

Figure 1. The diameters of the inhibition zones of ethanol extracts from five member Zingiberaceae against C. albicans and T. rubrum

Table 1. The crude extract

\begin{tabular}{lccc}
\hline Plants & Part of plants & Solvent (96\%) & Crude extract (\%) \\
\hline Curcuma longa & Rhizome & Ethanol & 19.7 \\
Alpinia galanga & Rhizome & Ethanol & 13.3 \\
Zingiber officinale var. rubrum & Rhizome & Ethanol & 15.1 \\
Zingiber officinale var. officinarum & Rhizome & Ethanol & 14.1 \\
Zingiber officinale var. amarum & Rhizome & Ethanol & 11.7 \\
\hline
\end{tabular}


Table 2. The results of the phytochemical analysis of rhizome extracts of the selected medicinal plants

\begin{tabular}{lcc}
\hline \multirow{2}{*}{ Plant extracts } & \multicolumn{2}{c}{ Secondary metabolites } \\
\cline { 2 - 3 } & Alkaloid & Flavonoid \\
\hline Curcuma longa & - & + \\
Alpinia galanga & - & + \\
Zingiber officinale var. rubrum & - & + \\
Zingiber officinale var. officinarum & - & + \\
Zingiber officinale var. amarum & - & + \\
\hline
\end{tabular}

Note: +: Present; -: Absent.

Research for antifungal agents from natural ingredients has become an important effort, given the higher and many levels of antibiotic resistance among pathogenic fungi. One effort in this study focused on the use of Zingiberaceae members (Curcuma longa, Alpinia galanga W, Zingiber officinale var. rubrum, Zingiber officinale var. officinarum and Zingiber officinale var. amarum), which are widely available, and less expensive. Thus, the research of alternative medicines and natural from plants against microbial pathogenic has become an important concern all over the world (Gechev et al. 2014).

The antifungal activities of the five extracts were assayed in vitro by agar diffusion method against $C$. albicans and T. rubrum. All plants demonstrated the zones of inhibition against $C$. albicans and $T$. rubrum. The diameters of the zones of inhibition with various concentrations $\mathrm{Cl}, \mathrm{Ag}(0.25-1.00 \mathrm{mg} / \mathrm{mL})$ and $\mathrm{Zr}$, Zo and $\mathrm{Za}(0.05-0.2 \mathrm{mg} / \mathrm{mL})$ are presented in Figure 1 . The extract showed antifungal activity against $C$. albicans in the agar well diffusion assay (10.2-27.1 $\mathrm{mm}$ inhibition diameter) and against $T$. rubrum (27.3-44.3 mm inhibition diameter). These results are in accordance with (Murugesh et al. (2019) wherethey studied potent antifungal action of $C$. longa (alcoholic extract) against $C$. albicans. A. galanga has antifungal activity against filamentous fungi (Handajani and Purwoko 2008), Z. officinale (ginger) had pronounced antifungal activity, including strains that were highly resistant to amphotericin B and ketoconazole (Ficker et al. 2003).

Flavonoids were present in all rhizomes of tested plants. These bioactive compounds have been reported to be used by plants for protection against bacterial and are responsible for antimicrobial activity (Khalid et al. 2019; Kumar and Pandey 2013). The mechanism of antifungal activity flavonoids compound in the study still unknown but according to Herrera et al. (2010); Paula et al. (2012); Yousefbeyk et al. (2014), flavonoids inhibit the human fungal pathogens. Flavonoids isolated from Helichrysum chasmolycicum were able to inhibit $C$. albican (Süzgeçselçuk and Birteksöz 2011), whereas Flavonoids isolated from Camellia sinensis were able to inhibit $T$. rubrum (Buzzini et al. 2009). Flavonoids inhibits efflux pump in fungi (Serpa et al. 2012).

In conclusion, the extract showed antifungal activity against $C$. albicans in the agar well diffusion assay (10.2$27.1 \mathrm{~mm}$ inhibition diameter) and against T. rubrum (27.3-
$44.3 \mathrm{~mm}$ inhibition diameter). The data have revealed that all rhizomes have the potential to be developed as antifungal agents, particularly against $C$. albicans and T. rubrum.

\section{REFERENCES}

Adnan A, Ahmed A. 2019. Phytochemical screening and in vitro antibacterial and anticancer activities of the aqueous extract of Cucumis sativus. Saudi J Biol Sci 26: 600-604. DOI: 10.1016/j.sjbs.2018.07.012.

Akter J, Hossain MA, Sano A, Takara K, Islam MZ, Hou DX. 2018. Antifungal activity of various species and strains of turmeric ( Curcuma spp.) against Fusarium Solani Sensu Lato. Pharm Chem J 52 (4): 320-325. DOI: 10.1007/s11094-018-1815-4.

Al-dhabi NA. Arasu MV. 2016. Quantification of phytochemicals from commercial Spirulina products and their antioxidant activities. EvidBased Compl Altern Med 2016: 7631864. DOI: $10.1155 / 2016 / 7631864$

Ashley ED, Drew R, Johnson M, Danna R, Dabrowski D, Walker V, Prasad M, Alexander B, Perfect GPJ. 2012. Cost of invasive fungal infections in the era of new diagnostics and expanded treatment options. Pharmacotheraphy 32 (10): 890-901. DOI: 10.1002/j.18759114.2012.01124.

Boral H, Metin B, Döğen A, Seyedmousavi S, Ilkit M. 2017. Overview of selected virulence attributes in Aspergillus fumigatus, Candida albicans, Cryptococcus neoformans, Trichophyton rubrum, and Exophiala dermatitidis. Fungal Genet Biol 111: 92-107. DOI: 10.1016/j.fgb.2017.10.008.

Brown GD, Denning DW, Gow NAR, Levitz SM, Netea MG, White TC. 2012. Hidden Killers: Human Fungal Infections. Sci Transl Med 4 (165): 165rv13-165rv13. DOI: 10.1126/scitranslmed.3004404.

Buzzini P, Vignolini P, Goretti M, Turchetti B, Branda E, Marchegiani E, Pinelli P, Omani A. 2009. Green Tea Catechins: A Class of Molecules with Antimicrobial Activity Handbook of Green Tea and Health Research. Nova Science Publishers, Inc., New York.

Calandra T, Roberts JA, Antonelli M, Bassetti M, Vincent J. 2016. Diagnosis and management of invasive candidiasis in the ICU: an updated approach to an old enemy. Crit Care 20: 125. DOI: 10.1186/s13054-016-1313-6.

Conti S, Radicioni G, Ciociola T, Longhi R, Polonelli L, Gatti R, Cabras T, Messana I, Castagnola M, Vitali A. 2013. Structural and functional studies on a proline-rich peptide isolated from swine saliva endowed with antifungal activity towards Cryptococcus neoformans. BBA Biomembr 1828: 1066-1074. DOI: 10.1016/j.bbamem.2012.12.013.

Cretton S, Oyarzún A, Righi D, Sahib L, Kaiser M, Christen P, Fajardo V. 2017. A new antifungal and antiprotozoal bibenzyl derivative from Gavilea. Nad Prod Res 32: 695-701. DOI: 10.1080/14786419.2017.1338287.

Soetojo SD, Astari L. 2016. Profil pasien baru infeksi kandida pada kulit dan kuku. Berk Ilmu Kesehat Kulit dan Kelamin 28: 34-41. [Indonesian]

Diniyah N, Alam B, Lee S. 2020. Antioxidant potential of non-oil seed legumes of Indonesian's ethnobotanical extracts. Arab J Chem. DOI: 10.1016/j.arabjc.2020.02.019.

Elango G, Roopan SM, Al-dhabi NA, Arasu MV, Damodharan KI, Elumalai K. 2016. Cocos nucifera coir-mediated green synthesis of Pd NPs and its investigation against larvae and agricultural pest. Artif Cells Nanomed Biotechnol 45 (8): 1581-1587. DOI: 10.1080/21691401.2016.1262382.

Espino M, Solari M, Fernández de los Á, Boiteux J, Gómez MR, Silva MF. 2019. Nades-mediated folk plant extracts as novel antifungal agents against Candida albicans. J Pharm Biomed Anal 167: 15-20. DOI: 10.1016/j.jpba.2019.01.026.

Ficker CE, Arnason JT, Vindas PS, Alvarez LP, Akpagana K, Gbéassor M, Souza CD, Smith ML. 2003. Inhibition of human pathogenic fungi by ethnobotanically selected plant extracts. Mycoses 46 (1-2): 29-37. DOI: 10.1046/j.1439-0507.2003.00838.x.

Gechev TS, Hille J, Woerdenbag HJ, Benina M, Mehterov N, Toneva V, Fernie AR, Mueller-roeber B. 2014. Natural products from resurrection plants: Potential for medical applications. Biotechnol Adv 32: 1091-1101. DOI: 10.1016/j.biotechadv.2014.03.005.

Ghafoor K, Juhaimi FAl, Ozcan MM, Uslu N, Babiker EE, Ahmed IAM. 2020. Total phenolics, total carotenoids, individual phenolics and 
antioxidant activity of ginger (Zingiber officinale) rhizome as affected by drying methods. LWT 126: 109354. DOI: 10.1016/j.lwt.2020.109354.

Ghannoum M, Isham N. 2014. Fungal Nail Infections (Onychomycosis): A Never-Ending Story? PLoS Pathog 10 (6): e1004105. DOI: 10.1371/journal.ppat.1004105.

Handajani NS, Purwoko T. 2008. Aktivitas ekstrak rimpang lengkuas ( Alpinia galanga ) terhadap pertumbuhan jamur Aspergillus spp. penghasil aflatoksin dan Fusarium moniliforme. Biodiversitas 9: 161164. DOI: 10.13057/biodiv/d090301.

Herrera CL, Alvear M, Barrientos L, Montenegro G, Salazar LA. 2010. The antifungal effect of six commercial extracts of Chilean propolis on Candida spp. Ciencia e Investigación Agraria 37 (1): 75-84. DOI: http://dx.doi.org/10.4067/S0718-16202010000100007.

Hube B, Hay R, Brasch J, Veraldi S, Schaller M. 2015. Dermatomycoses and inflammation: The adaptive balance between growth, damage, and survival. J Mycol Med 25: 44-58. DOI: 10.1016/j.mycmed.2014.11.002.

Kader G, Nikkon F, Rashid MA, Yeasmin T. 2011. Antimicrobial activities of the rhizome extract of Zingiber zerumbet Linn. Asian Pac J Trop Biomed 1: 409-412. DOI: 10.1016/S2221-1691(11)60090-7.

Khalid M, Bilal M, Dan-feng H. 2019. Role of flavonoids in plant interactions with the environment and against human pathogens - A review. J Integr Agric 18: 211-230. DOI: 10.1016/S20953119(19)62555-4.

Kollef M, Micek S, Hampton N, Doherty JA, Kumar A. 2012. Septic shock attributed to Candida infection: Importance of empiric therapy and source control. Clin Infect Dis 54: 1739-1746. DOI: $10.1093 / \mathrm{cid} / \mathrm{cis} 305$.

Kong QT, Du X, Yang R, Huang S, Sang H, Liu WD. 2015. Chronically recurrent and widespread tinea corporis due to Trichophyton rubrum in an immunocompetent patient. Mycopathologia 179: 293-297. DOI: 10.1007/s11046-014-9834-5.

Kumar S, Pandey Ak. 2013. Chemistry and biological activities of flavonoids: An Overview. Sci World J 1-16. DOI: http://dx.doi.org/10.1155/2013/162750.

Lewis MA, Williams D. 2017. Diagnosis and management of oral candidosis. $\mathrm{Br}$ Dent J 223 (9): 675-681. DOI: 10.1038/sj.bdj.2017.886.

Lortholary O, Renaudat C, Sitbon K, Madec Y, Denoeud-Ndam L, Wolff M, Fontanet A, Bretagne S, Dromer F. 2014. Worrisome trends in incidence and mortality of candidemia in intensive care units (Paris area, 2002-2010). Intensive Care Med 40: 1303-1312. DOI: 10.1007/s00134-014-3408-3.

Mahomoodally MF, Aumeeruddy MZ, Rengasamy KRR, Roshan S, Hammad S, Pandohee J, Hu X, Zengin G. 2019. Ginger and its active compounds in cancer therapy: From folk uses to nano- therapeutic applications. Semin Cancer Biol 1-10. DOI: 10.1016/j.semcancer.2019.08.009.

Manh D, Valan M, Jeon J, Ji Y, Kwon S, Al-dhabi NA, Un S. 2017. Medically important carotenoids from Momordica charantia and their gene expressions in different organs. Saudi J Biol Sci 24: 1913-1919. DOI: 10.1016/j.sjbs.2017.11.039.

McManus B, Coleman D. 2014. Molecular epidemiology, phylogeny and evolution of Candida. Infect Genent Evol 21: 166-178. DOI: 10.1016/j.meegid.2013.11.008.

Muadcheingka T, Tantivitayakul P, Candida N. 2015. ScienceDirect Distribution of Candida albicans and non-albicans Candida species in oral candidiasis patients: Correlation between cell surface hydrophobicity and biofilm forming activities. Arch Oral Biol 60: 894-901. DOI: 10.1016/j.archoralbio.2015.03.002.

Murugesan S, Venkateswaran MR, Jayabal S, Periyasamy S. 2020 Evaluation of the antioxidant and anti-arthritic potential of Zingiber officinale Rosc . by in vitro and in silico analysis. South Afr J Bot 130: 45-53. DOI: 10.1016/j.sajb.2019.12.019.

Murugesh J, Annigeri RG, Mangala GK, Mythily PH, Chandrakala J, 2019. Evaluation of the antifungal efficacy of different concentrations of Curcuma longa on Candida albicans: An in vitro study. J Oral Maxillofac Pathol 23: 305. DOI: 10.4103/jomfp.JOMFP.

Oro D, Heissler A, Rossi EM, Scapin D, Malheiros P, Boff E. 2015 Antifungal activity of natural compounds against Candida species isolated from HIV-positive patients. Asian Pac J Trop Biomed 5: 781-784. DOI: 10.1016/j.apjtb.2015.07.011.

Pappas PG, Kauffman CA, Andes DR, Clancy CJ, Marr KA, Ostroskyzeichner L, Reboli AC, Schuster MG, Vazquez JA, Walsh TJ, Zaoutis TE, Sobel JD. 2016. Clinical practice guideline for the management of Candidiasis : 2016 Update by the Infectious Diseases Society of
America. Clin Infect Dis 62: 1-50. DOI: 10.1093/cid/civ933.

Pathania S, Rudramurthy SM, Narang T, Saikia UN, Dogra S. 2018. A prospective study of the epidemiological and clinical patterns of recurrent dermatophytosis at a tertiary care hospital in India. Indian J Dermatol Venereol Leprol 678-684. DOI: .DOI: 10.4103/ijdvl.IJDVL_645_17.

Paula M, Marcela C, Céliz G, Daz M, Liliana S. 2012. Efficacy of fl avanones obtained from citrus residues to prevent patulin contamination. Food Res Intl 48: 930-934. DOI: 10.1016/j.foodres.2012.02.003.

Piras A, Jose M, Alves J, Falconieri D, Porcedda S, Maxia A. 2018. Ocimum tenuiflorum L . and Ocimum basilicum L ., two spices of Lamiaceae family with bioactive essential oils. Ind Crops Prod 113: 89-97. DOI: DOI: 10.1016/j.indcrop.2018.01.024

Prastiyanto, ME, Tama PD, Ananda N, Wilson W, Mukaromah, AH 2020a. Antibacterial potential of Jatropha sp. latex against MultidrugResistant Bacteria. Int J Microbiol 2020. DOI: DOI: $10.1155 / 2020 / 8509650$.

Prastiyanto ME, Wardoyo FA, Wilson W, Darmawati S. 2020 b. Antibacterial activity of various extracts of Averrhoa bilimbi against Multidrug Resistant Bacteria. Biosaintifika J Biol Biol Educ 12 (2): 163-168. DOI: 10.15294/biosaintifika.v12i2.23600.

Puspitasari A, Kawilarang AP, Ervianti E. 2019. Profil Pasien Baru Kandidiasis (Profile of New Patients of Candidiasis). Berk Ilmu Kesehat Kulit dan Kelamin 31: 24-34. [Indonesian]

Reiss E, Shadomy H, Lyon GM. 2012. Fundamental medical mycology. John Wiley \& Sons Inc., New Jersey.

Rudramurthy SM, Shankarnarayan SA, Dogra S, Shaw D, Mushtaq K, Paul RA. 2018. Mutation in the squalene epoxidase gene of Trichophyton interdigitale and Trichophyton rubrum associated with allylamine resistance. Antimicrob Agents Chemother 62: e02522-17. DOI: 10.1128/AAC.02522-17

Sales MDC, Costa HB, Fernandes PMB, Ventura JA, Meira DD. 2016. Antifungal activity of plant extracts with potential to control plant pathogens in pineapple. Asian Pac J Trop Biomed 6: 26-31. DOI: 10.1016/j.apjtb.2015.09.026.

Serpa R, Franc EJG, Furlaneto-maia L, Andrade GTJ. 2012. In vitro antifungal activity of the flavonoid baicalein against Candida species 1704-1708. DOI: 10.1099/jmm.0.047852-0.

Siigur J, Aaspollu A, Siigur E. 2019. Biochemistry and pharmacology of proteins and peptides purified from the venoms of the snakes Macrovipera lebetina subspecies. Toxicon 158: 16-32. DOI: 10.1016/j.toxicon.2018.11.294.

Singh A, Masih A, Khurana A, Gupta M, Hagen FJfM, Chowdhary A. 2018. High terbinafine resistance in Trichophyton interdigitale isolates in Delhi, India harbouring mutations in the squalene epoxidase gene. Mycoses 61: 477-484. DOI: 10.1111/myc.12772.

Sipriyadi, Lestari Y, Wahyudi AT, Meryandini A, Thenawidjaja M, Suhartono. 2016. Exploration of potential actinomycetes from CIFOR Forest origin as antimicrobial, antifungus, and producing extracellular xylanase. Biosaintifika 8: 96-104. DOI: 10.15294/biosaintifika.v8i1.5052.

Süzgeç-selçuk S, Birteksöz AS. 2011. Flavonoids of Helichrysum chasmolycicum and its antioxidant and antimicrobial activities. South Afr J Bot 77: 170-174. DOI: 10.1016/j.sajb.2010.07.017.

Vincent J, Marshall J, Anzueto A, Martin CD, Gomersall C, Sakr Y, Reinhard K. 2009. International study of the prevalence and outcomes of infection in intensive care units. Jama 302: 2323-2329. DOI: 10.1001/jama.2009.1754.

Wadood A, Ghufran M, Jamal SB, Naeem M, Khan A, Ghaffar R, Asnad. 2013. Phytochemical analysis of medicinal plants occurring in local area of mardan. Biochem Anal Biochem 02: 2-5. DOI: 10.4172/21611009.1000144.

Wibowo DP, Mariani R, Hasanah SU, Aulifa DL. 2020. Chemical constituents, antibacterial activity and mode of action of elephant ginger (Zingiber officinale var. officinale) and emprit ginger rhizome (Zingiber officinale var. amarum) essential oils. Pharmacogn J 12: 404-409. DOI: $10.5530 / \mathrm{pj} .2020 .12 .62$

Yousefbeyk F, Gohari AR, Hashemighahderijani Z, Ostad SN. 2014. Bioactive terpenoids and flavonoids from Daucus littoralis Smith subsp . hyrcanicus Rech. f, an endemic species of Iran. DARU J Pharm Sci 22 (1): 1-6. DOI: 10.1186/2008-2231-22-12.

Zhan P, Liu W. 2017. The changing face of dermatophytic infections worldwide. Mycopathologia 182: 77-86. DOI: 10.1007/s11046-0160082-8. 
